TECHNICAL TRANSACTIONS 1/2019

MECHANICS

DOI: $10.4467 / 2353737$ XCT.19.014.10054 SUBMISSION OF THE FINAL VERSION: 18/12/2018

Marcin Noga orcid.org/0000-0002-3738-2220

noga@pk.edu.pl

\author{
Zdzisław Juda orcid.org/0000-0001-6795-4536 \\ Institute of Automobiles and Internal Combustion Engines, Faculty of Mechanical \\ Engineering, Cracow University of Technology
}

\title{
THE APPLICATION OF NIMH BATTERIES IN A LIGHT-DUTY ELECTRIC VEHICLE
}

\section{ZASTOSOWANIE AKUMULATORÓW NIMH W LEKKIM UŻYTKOWYM POJEŹDZIE ELEKTRYCZNYM}

\begin{abstract}
This article presents the results of experimental tests and simulations of a light-duty electric vehicle, in which the original lead-acid battery pack was replaced with a lightweight pack of nickel-metal-hydride (NiMH) batteries, which enabled a significant increase to the vehicle's load capacity. The research was mainly focused on the aspect of electricity consumption and prediction of the range of the vehicle equipped with a new battery pack. The operation of a vehicle with total weights of $500 \mathrm{~kg}$ and $740 \mathrm{~kg}$ was analysed. Recorded vehicle speed waveforms were used to simulate vehicle motion in the Matlab/Advisor environment. The experiments showed a reduction in the specific energy consumption of a vehicle of lower weight, while simulation tests showed good compliance of the results of electricity consumption with experiments in relation to both the considered total vehicle weights.
\end{abstract}

Keywords: electric vehicle; NiMH battery; energy consumption; simulation; experimental research

\section{Streszczenie}

W artykule zaprezentowano wyniki badań eksperymentalnych i symulacyjnych lekkiego, elektrycznego pojazdu użytkowego, w którym oryginalny zestaw akumulatorów kwasowo-ołowiowych został zastąpiony lekkim pakietem akumulatorów niklowo-metalowo-wodorkowych, co pozwoliło znacznie zwiększyć ładowność pojazdu. Badania skupiono głównie na aspekcie zużycia energii elektrycznej i predykcji zasięgu pojazdu wyposażonego w nowy zestaw akumulatorów. Analizowano zachowanie pojazdu o masie $500 \mathrm{~kg}$ oraz $740 \mathrm{~kg}$. Przebiegi zmian prędkości zarejestrowane podczas jazd testowych użyto do przeprowadzenia symulacji ruchu pojazdu w środowisku Matlab/Advisor. Wyniki badań eksperymentalnych wskazaly na ograniczenie jednostkowego zużycia energii przez pojazd o mniejszej masie, natomiast w badaniach symulacyjnych uzyskano dobrą zgodność zużycia energii z rezultatami eksperymentów w obu analizowanych przypadkach.

Słowa kluczowe: pojazd elektryczny, akumulatory NiMH, zużycie energii, symulacja, badania eksperymentalne 


\section{Introduction}

\subsection{Background}

Electric vehicles are gaining more and more popularity as a form of road transport. Some experts estimate that in 2030, the share of electric vehicles will be average $25 \%$ of vehicles travelling on roads across the whole world[3]. According to the same prognosis, a significant proportion of the remaining vehicles will have hybrid propulsion systems, in which apart from the internal combustion engine, an electric motor can usually be found. Internal combustion engines are still being developed; however, it is clear that over the course of dozens of years, the electric drive will be a replacement for the internal combustion engine in automotive applications [12]. The basic advantage of replacing propulsion from combustion engines in the automotive sector with the electric drive is their zero emission of toxic gases at the place of their use. In the wider context, one should take into account not only the methods of producing electricity in the area of vehicle use [13] and aspects related to energy and emissivity of production processes but also the recycling of waste electric vehicle components [6]. Particular attention should be paid to energy storage systems consisting mostly of electrochemical batteries.

Of the less significant benefits of replacing the internal combustion engine with the electric motor, one should mention the simplification of the drive system by eliminating the gearbox. This is possible due to the convenient output characteristics of electric motors, although recently, solutions of two-stage transmissions for electric cars that enable the improvement of the traction characteristics of the vehicle have appeared [16]. Among the basic problems in the development of pure electric drives in automotive applications, the most important are the relatively low capacity of energy storage systems based on the currently available types of batteries resulting in a low vehicle range [17]. Another problem linked to the growing popularity of electric vehicles is also the limited electricity supply possibilities in some countries resulting from the limited abilities of the electricity production system. In some countries, the only remedy is, in principle, the development of nuclear energy [2].

\subsection{Batteries in electric vehicles}

In the first vehicles with electric drive, lead-acid batteries were used [9]. In the following years, nickel-cadmium batteries were also employed; these have now been eliminated from vehicle applications due to their use of toxic cadmium. In automotive applications, nickel-metal-hydride batteries similar to NiCd battery began to be used [25]. Among other applications, these were found in the famous second-generation GM EV1 electric vehicle. For various reasons, they have not yet been widely used in vehicles that have exclusively electric drive mechanisms. Some authors even see the collusion of a fuel lobby involving blocking the development of high-capacity NiMH batteries [28]. However, it should be noted that the energy density of nickel-metal-hydride batteries is lower than for dynamically developing 
Li-ion batteries, and the price of $1 \mathrm{kWh}$ stored energy is relatively higher. Information from the research and development sector regarding the development of NiMH batteries with extremely high performance forecasts a wider application of this technology in electric vehicles. [21]. However, NiMH batteries have found a very common use in vehicles with hybrid drive systems [7] as a mature, non-problematic technology. Nowadays, energy storage systems in vehicles with pure electric drives are usually in the form of various types of lithium-ion batteries. The objective of engineers is to find batteries characterized by high specific energy and specific power with an increased number of work cycles and a reduction in production costs.

Lead-acid batteries are commonly used in light-duty commercial vehicles. This is mainly due to their low price, simple operation and the fact that they do not require battery management systems, which lithium-ion batteries require for safe and trouble-free operation [18]. The latter has begun to be used in golf buggy type vehicles in recent years however, this significantly raises the price of such vehicles. In addition, lithium-ion batteries are a less safe solution than lead-acid or nickel-hydride batteries. This is due to the use of flammable, organic and usually liquid electrolytes. There are relatively frequent known cases of fires, even explosions in electric vehicles equipped with lithium-ion batteries [10]. Moreover, in the case of Li-ion batteries, there is the phenomenon of 'thermal runaway'. This consists of an uncontrolled increase in the temperature of the battery leading to its combustion, and initiated in the process in which the critical temperature of this type of cell has been exceeded [4]. This phenomenon is practically non-existent in the case of nickel-metal-hydride batteries, which is their unquestionable advantage. Nickel-metal-hydride batteries do not require the balancing of individual cells in a serial connection, which is mandatory for lithium-based batteries. Yet another advantage of $\mathrm{NiMH}$ batteries in relation to $\mathrm{Li}$-ion batteries is the relatively troublefree recycling process of used batteries, in which many rare earth metals are recovered [5].

In the case of lithium-ion batteries, the recycling process is more difficult than for other batteries due to the significant differences in the chemical composition of materials used for the production of particular types of Li-ion cells. In the case of NiMH batteries, there are also differences in the materials used, especially for the negative electrode, but they do not cause such problems in recycling as is the case with Li-ion batteries.

\subsection{Comparison of the key parameters of the most important traction batteries}

As mentioned earlier, during the development of electric vehicles, various types of batteries have been used. A comparison of the most important parameters of traction batteries used in the past and modern electric vehicles is presented in Table 1; lead-acid batteries were also compared. Nowadays, these batteries are no longer used in passenger electric vehicles. This is primarily due to their low energy density and low cycle life. However, they can still often be found in currently produced golf carts, forklifts and vehicles for transport inside workplaces. Low prices of storage systems and low maintenance requirements are the most important considerations.

In modern full-size vehicles with electric drives, various types of lithium-based batteries are mainly used; this is especially due to their high specific energy, specific power and cycle life. These parameters are crucial for an electric vehicle energy storage system. Nickel-metal- 
-hydride batteries are currently used in vehicles with hybrid drives, but at the beginning of the present century they were used in small-series electric vehicles. Working in hybrid propulsion systems in the range of around $30-70 \%$ of the state of charge (SOC), nickel-metal-hydride batteries receive an exceptionally high durability, exceeding 10 years of operation.

Table 1. Parameters comparison of different type batteries used in electric vehicles [27]

\begin{tabular}{|c|c|c|c|}
\hline Key parameter & Lead-Acid & Ni-MH & Li-ion \\
\hline cell voltage $[\mathrm{V}]$ & 2.0 & 1.2 & $3.2-3.71$ \\
\hline specific energy $[\mathrm{Wh} / \mathrm{kg}]$ & $30-50$ & $60-120$ & $90-250$ \\
\hline specific power $[\mathrm{W} / \mathrm{kg}]$ & $\sim 180$ & up to 1300 & even 2500 \\
\hline internal resistance $[\mathrm{m} \Omega]$ & low & high & very low to moderate 1 \\
\hline cycle life $(80 \% \mathrm{DoD})$ & $200-300$ & $300-500$ & $500-2000$ \\
\hline charge time $[\mathrm{h}]$ & $8-16$ & $2-4$ & $1-4$ \\
\hline self-discharge $/$ month $[\%]$ & 5 & 30 & $<5$ \\
\hline peak load current & $<5 \mathrm{C}$ & usually $<5 \mathrm{C} 2$ & even>30 \\
\hline coulombic efficiency $[\%]$ & 90 & 903 & -20 to 60 \\
\hline discharge temperature $\left[{ }^{\circ} \mathrm{C}\right]$ & -20 to 50 & -20 to 65 & very complex 4 \\
\hline management system & simple & moderate & high \\
\hline total cost of storage system & low & moderate & protection circuit mandatory \\
\hline safety requirements & thermally stable & thermally stable, \\
\end{tabular}

1 - depending on cell chemistry; 2 - special design for automotive purposes - even 20C; 3 - fast charging, at slow charging $70 \% \max ; 4$ - precise control at the cell level

The comparison of batteries is not unambiguous in all aspects. This is due to the large number of Li-ion battery types and, to a lesser extent, the differences it the construction of $\mathrm{NiMH}$ batteries. They differ significantly in the materials used for construction, which results in differences in the obtained parameters. For example, $\mathrm{LiCo}_{2}$ batteries have almost twice the specific energy as $\mathrm{LiFePO}_{4}$, but they are not suitable for use in vehicles due to the low allowable discharge current. Regarding NiMH batteries, those used in hybrid vehicles have low internal resistance and a relatively high allowable load current (up to 20C), which also gives them high power density; however, specific energy is also lower than in Table 1 - below $50 \mathrm{Wh} / \mathrm{kg}$.

The key advantages and disadvantages of nickel-metal-hydride battery technology compared to Li-ion batteries in particular are listed below:

- NiMH batteries remain cheaper than batteries made with lithium technologies when considering the total cost of the energy storage system.

- The basic materials necessary for storing energy are hydrogen, nickel and titanium.

- They are characterised by high durability when used properly.

- The recycling of waste batteries is much easier than is the case with Li-ion batteries.

- They have high tolerance for increased temperature and a lack of propensity for selfignition. 
- Complex battery management systems that are mandatory for lithium-based batteries are not required for $\mathrm{NiMH}$ batteries.

- Nickel-metal-hydride batteries can be discharged to much lower SOC than lithiumbased batteries to ensure a high cycle life.

- The memory effect is eliminated in modern NIMH batteries.

- The lower cell voltage of NiMH batteries requires higher number of cells connected in series to have the same voltage. This is not favourable in point of reliability.

- Currently, mass-produced NiMH batteries have a lower energy density in comparison to lithium-based batteries.

- Due to the intensive heat generation, an efficient battery cooling system is required.

- They have high self-discharge - up to $30 \%$ per month.

In summary, NiMH batteries have some advantages over Li-ion batteries; however, on key issues, such as e.g. specific energy, lithium-based batteries are currently preferred for application in battery-powered electric vehicles. The recent development in nickel-metalhydride batteries which is described in next section can change this situation.

\subsection{Recent developments in the field of NiMH batteries}

The development of NiMH batteries is mainly based on the search for metal alloys with new structures that enable higher specific energy levels [22].

Alloys known under the names $\mathrm{AB}_{5}$ and $\mathrm{AB}_{2}$ are characterised by their ability to store hydrogen and their good working parameters [23]. Alloy $\mathrm{AB}_{5}$ is a mixture of nickel (B) - as a metal that does not form hydrides - with other metals that do have a tendency to form hydrides, e.g. Ce, $\mathrm{Nd}$, La (A). Nickel doped with other materials, e.g. Sn, Al., Co, shows greater stability. In turn, $\mathrm{AB}_{2}$ alloys, called Laves phases, contain metals such as $\mathrm{Hf}, \mathrm{Zr}$ or Ti on the $\mathrm{A}$ side and metals like $\mathrm{Mn}, \mathrm{Ni}$ or $\mathrm{Cr}$ on the $\mathrm{B}$ side. $\mathrm{AB} 2$ alloys are characterised by higher capacitances if used as negative electrodes in batteries. $\mathrm{AB}_{2}$ alloys occur in three structures:

- hexagonal C14

- regular C15

- hexagonal C36

NiMH batteries using $\mathrm{AB}_{2}$ alloys were used in the GM EV1 car in 1999. The specific energy in these batteries was $52 \mathrm{Wh} / \mathrm{kg}$. Research and development work in the field of $\mathrm{NiMH}$ batteries focuses mainly on the search for new alloys for electrodes and new electrolytes. In general, materials for negative electrodes are called Ni-TM, where TM stands for transition metal; the following alloys are considered: Ni-Mn, Ni-Fe, Ni-Co and Ni-Zn. Due to the toxic effects of cadmium, the $\mathrm{Ni}-\mathrm{Cd}$ alloy was abandoned. Of the batteries present on the market, the best parameters are characterised by those containing the Ni-Zn alloy $[1,22]$. At a relatively low cost, they have a high energy density (about $70 \mathrm{Wh} / \mathrm{kg}$ ) although they do not have a very long life, which limits their use in electric vehicles. They are mainly used in power backup systems (UPS). As part of a large grant funded by the US DoE, the RANGE (robust affordable next-generation energy storage system) project was created [22]. 
The global BASF company is performing intensive research on more efficient $\mathrm{NiMH}$ batteries - the goal is to obtain specific energy in the range of $600-1,200 \mathrm{Wh} / \mathrm{kg}$, and prices in the range of $150 \$$ for $1 \mathrm{kWh}$. As the main contractor, BASF conducted intensive research on the development of electrode and electrolyte materials for the next-generation $\mathrm{Ni}-\mathrm{MH}$ batteries. The main goals are low cost and high specific energy. One of the tasks performed by BASF was the development of high-capacity MH alloys that contain MgNi, BCC (body-centred cubic) alloys and Si. The second task was to obtain a substitute for the electrolyte currently used to reduce corrosion and for the possible improvement of the redox reaction. Subsequent tasks include the development of active materials for positive electrodes and integration into the form of ready-made battery. The final goal is to commercialize the new EV Energy storage.

In the field of materials for the negative electrode, 5 alloys were tested: $\mathrm{MgNi}, \mathrm{Mg}_{2} \mathrm{Ni}$, BCC-C14, BCC and Si. Of these, the BCC-C14 alloy was rated higher, which showed high capacity with correct cycle stability. The capacity the BCC-C14 alloy was $30 \%$ higher than the classic $\mathrm{AB}_{5}$ alloy. In the research and development of the new electrolyte, many samples of the modified aqueous $\mathrm{KOH}$ were tested [20]. Research has shown that the way to increase energy density is to achieve higher cell voltage; therefore, the focus was on IL fluids (ionic liquid), consisting of only anions and cations and characterised by, among other features, high thermal stability, high ion conductivity and non-flammability. Finally, three variants of cells were made, of which the sealed pouch cell showed a specific energy of $127 \mathrm{Wh} / \mathrm{kg}$ [19].

\section{Aim and scope of the work}

The aim of the described work was to develop a new lightweight energy storage system basing on a nickel-metal-hydride battery for a light-duty electric vehicle for a golf cart type of vehicle which originally had a set of lead-acid flooded batteries. The motivation for the authors was the fact that examples of the use of a NiMH battery in a similar light-duty electric vehicle were not presented in the available sources.

The developed energy storage system was composed on the basis of a battery taken from a hybrid electric vehicle. This operation was aimed at significantly increasing the vehicle's loading capacity by reducing its weight (by around $200 \mathrm{~kg}$ ). The expense of this approach was a reduction in the vehicle's range; however, in the case of transport within workplaces, there are applications in which the 10-km-range of the vehicle on a single charge is sufficient and the load capacity of the vehicle becomes the most important factor. In the discussed case, replacing batteries with a total weight of $240 \mathrm{~kg}$ for a nickel-metal-hydride battery with a weight of $40 \mathrm{~kg}$ allows increasing the loading capacity to $350 \mathrm{~kg}$ or up to over $400 \mathrm{~kg}$ if no passenger is carried. This is an increase of $130 \%$ compared to the original value.

The used nickel-metal hydride batteries have a power density of $1,000 \mathrm{~W} / \mathrm{kg}$, which makes it possible to draw high current from them while maintaining a high level of durability. Lead-acid batteries with a similar total weight $(40 \mathrm{~kg})$ and a nominal voltage of $48 \mathrm{~V}$ have a significantly lower current capacity. In addition, traction batteries of this size (with a capacity of $30 \mathrm{Ah}$ ) that 
are resistant to deep-cycle discharge are not produced. It would be possible to use a pack of starter batteries, but such batteries used in an electric vehicle would be subject to rapid wear.

In the first stage of work, after development of the new storage system and composing of data acquisition system, it was possible to conduct experimental tests of the vehicle. Two test drives were performed - one without load and one with a load of $240 \mathrm{~kg}$. During the test drives, the vehicle's speed, battery voltage, battery current and temperature were recorded. This primarily enabled calculation of the influence of weight on the energy consumption of the vehicle. The recorded vehicle's speed profiles were also needed in the simulation that followed.

The second stage of work was executed using the Matlab/ADVISOR environment. The aim was to develop a model of electric vehicle using a NiMH battery, which allows the fast simulation of energy consumption and estimation of the vehicle's range and how this is affected by its weight without the need for experimental tests.

\section{Development of a new storage system}

\subsection{Tested vehicle}

The object of the research was a light-duty vehicle with a Melex type 945DS electric drive. Vehicles of this kind are often used to transport goods within workplaces, as golf carts, or with increasing frequency to transport tourists in historical city centres. The vehicle is shown in Fig. 1.

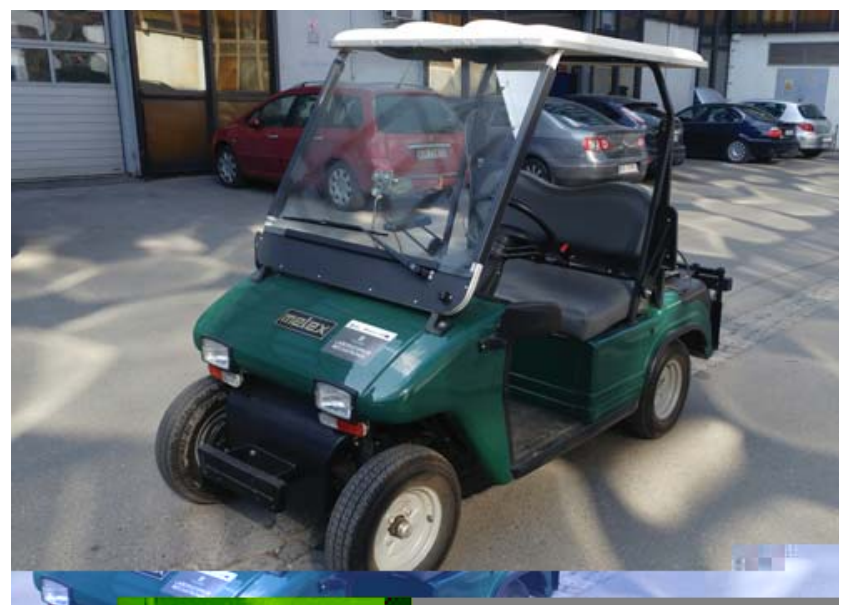

Fig. 1. The tested electric vehicle

The tested vehicle was equipped with an electric system with a nominal voltage of $48 \mathrm{~V}$ and a DC drive motor. Such motors are still popular in new vehicles of this type, mainly due to the low price of a DC motor with a controller compared to an asynchronous motor with an inverter. The basic technical data of the test vehicle with the factory battery is presented in Table 2 . 
Table 2. Technical data of the Melex 945DS tested vehicle with a factory-type battery [8]

\begin{tabular}{|c|c|c|c|}
\hline Parameter & Value & Parameter & Value \\
\hline $\begin{array}{c}\text { length } \mathrm{x} \text { width; } \\
\text { wheelbase }\end{array}$ & $\begin{array}{c}2660 \times 1230 ; \\
1660 \mathrm{~mm}\end{array}$ & rated armature current & $100 \mathrm{~A}$ \\
\hline net vehicle weight & $380 \mathrm{~kg}$ & rated output power & $3.9 \mathrm{~kW}$ at $4300 \mathrm{rpm}$ \\
\hline vehicle capacity & 2 people $+150 \mathrm{~kg}$ load & rated torque & $8.2 \mathrm{Nm}$ \\
\hline factory battery type & Trojan T-125 $(6 \mathrm{~V})$ & max. motor efficiency & $75 \%$ \\
\hline nominal voltage & $48 \mathrm{~V}$ & total gear ratio & 16 \\
\hline $\begin{array}{c}\text { battery capacity } \\
(10 \mathrm{~h})\end{array}$ & $221 \mathrm{Ah}$ & tyre size & $145 / 80 \mathrm{~B} 10$ \\
\hline motor type & DC, separately excited & maximum speed & $\sim 30 \mathrm{~km} / \mathrm{h}$ \\
\hline motor symbol & DV3-4006AA & vehicle range & $\sim 60 \mathrm{~km}$ \\
\hline
\end{tabular}

The motor was managed using a programmable Curtis 1266 controller designed for operation with a nominal voltage of $36 \mathrm{~V}$ or $48 \mathrm{~V}$ and with a maximum continuous armature current of $140 \mathrm{~A}$. The controller was based on the MOSFET technology with the voltage, armature current, and excitation current adjustable by means of pulse width modulation (PWM). The frequency of PWM is $16 \mathrm{kHz}$. In the control circuit of the excitation winding, the transistors are connected in an H-bridge configuration, so that the polarity of the supply voltage can be changed, which allows changing the direction of motor rotation. There is the possibility of changing the number of configuration parameters, such as maximum speed, allowable motor armature and excitation currents, and generator operation. There is also the possibility to delay the start and intensity of the regenerative braking process. Changing of the controller settings is made using a dedicated Curtis 1311 programming tool.

The original electricity storage system is based on lead-acid batteries with a capacity of $221 \mathrm{Ah}(10 \mathrm{hrs}$.). The energy stored in the original battery pack is $10.61 \mathrm{kWh}$, which allows driving a distance of about $60 \mathrm{~km}$.

\subsection{Applied NiMH modules and development of a new battery pack}

For the work described in this article, a traction battery pack from a Toyota Prius NHW11 produced in 2000-2003 (MY '00) was used. The pack is composed of 38 modules with a nominal voltage of $7.2 \mathrm{~V}$ connected in series; this gives a nominal voltage of $273.6 \mathrm{~V}$ for the whole pack. The modules were manufactured by Panasonic, and in a slightly modified form, they were also used in the 2nd generation Prius ( $M Y$ '03) and $3^{\text {rd }}$ generation ( $M Y$ '09) vehicles. The list of basic data of the NiMH battery modules used in the test vehicle is presented in Table 3.

As shown in Table 3, the applied batteries have a relatively low specific energy; however, they have a very high specific power, which allows drawing a high current. The nominal voltage of the electric system of a Melex commercial vehicle is $48 \mathrm{~V}$. In order to match the voltage of the NiMH battery pack to the voltage of the Melex vehicle electric system five adjacent modules were connected in parallel. This resulted in there being seven sections of 
Table 3. Basic technical data of Toyota Prius NHW11 battery modules $[14,15]$

\begin{tabular}{|c|c|}
\hline Parameter & Value/Description \\
\hline cell type & NiMH \\
\hline manufacturer & Panasonic \\
\hline module shape & prismatic \\
\hline width $x$ length $\mathrm{x}$ height, $\mathrm{mm}$ & $275 \times 19.6$ x 106 \\
\hline rated voltage, $\mathrm{V}$ & $7.2(6$ cells in series $)$ \\
\hline module capacity, $\mathrm{Ah}$ & 6.5 \\
\hline module weight, $\mathrm{kg}$ & 1.05 \\
\hline specific energy, $\mathrm{Wh} / \mathrm{kg}$ & 44.6 \\
\hline specific power, $\mathrm{W} / \mathrm{kg}$ & 1000 \\
\hline C-rate during discharge $($ peak $)$ & $\sim 20$ \\
\hline
\end{tabular}

five modules with an equivalent capacity of $32.5 \mathrm{Ah}$. The sections were connected in series, which allowed the obtaining of a nominal voltage of $50.4 \mathrm{~V}$; this is a value very similar to the $48 \mathrm{~V}$ mentioned above. In this way, 35 of the 38 Prius batteries in the package were used. Figure 2 shows a fragment of the connection diagram of the NiMH battery of the Prius MY '00, as well as a battery pack after adapting the connections for use in the Melex vehicle.
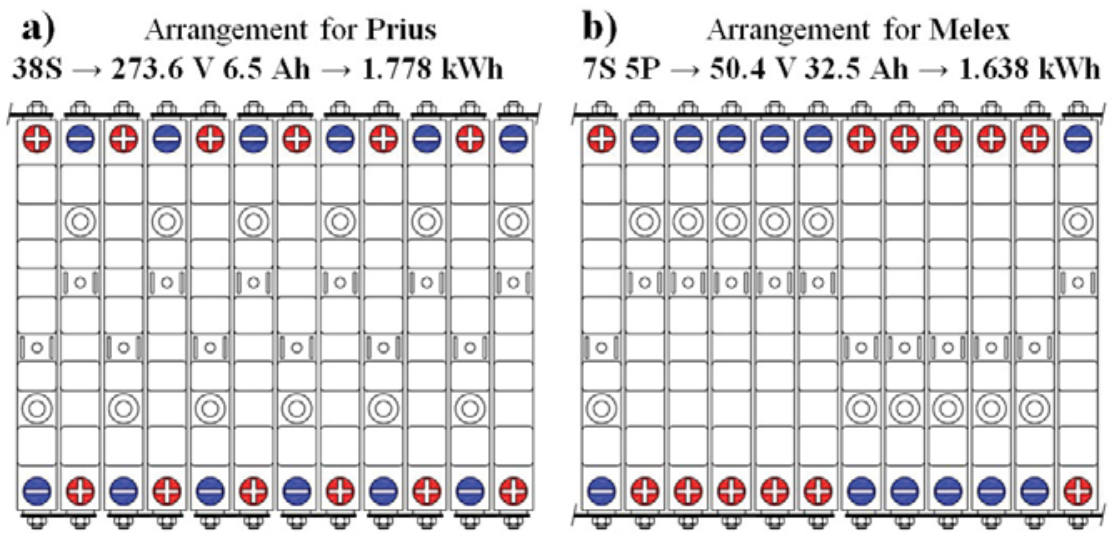

Fig. 2. A fragment of the Prius battery pack before (a) and after adaptation for use in a Melex electric vehicle (b)

A view of the rear part of the vehicle with the installed battery pack from the Prius is shown in Fig. 3. The combining of modules in sections was established using connectors made of 2-mm-thick copper sheeting.

During the tests, the battery was positioned as shown in Fig. 3. Currently work is underway to locate the battery in the place of the original battery (under the driver and passenger seats).

In the summary of this part of the work, Table 4 presents a comparison of the key parameters of both energy storage systems: the original lead-acid system; the newlydeveloped, lightweight system built on the basis of nickel-metal-hydride battery modules. 


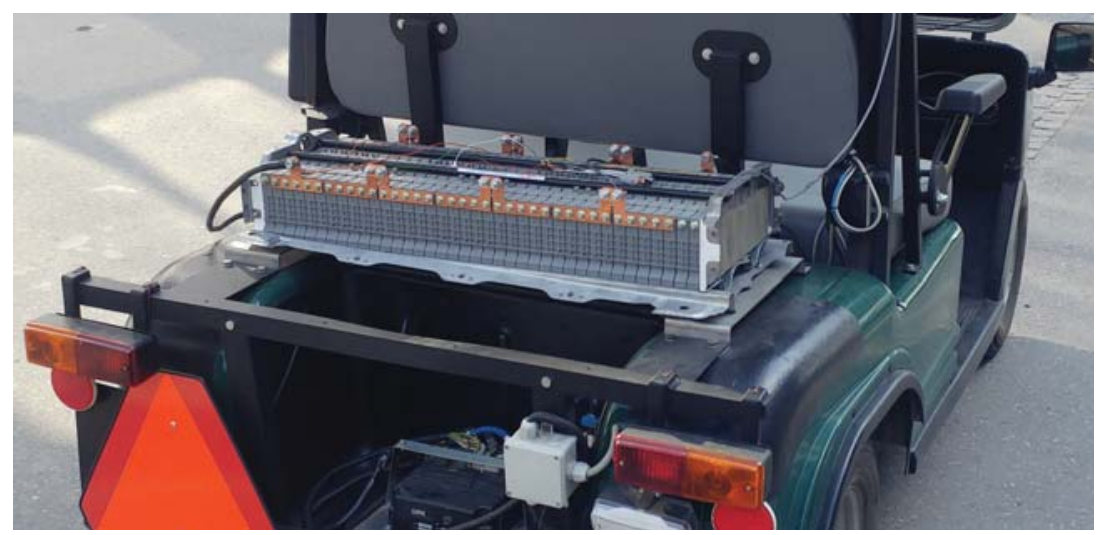

Fig. 3. Rear part of the tested vehicle with NiMH battery

Table 4. Comparison of key parameters of the original lead-acid and the newly-developed NiMH packs for a light-duty electric vehicle

\begin{tabular}{|c|c|c|}
\hline Parameter & Lead-acid & NiMH \\
\hline module rated voltage, $\mathrm{V}$ & 6 & 7.2 \\
\hline connection type inside a module & $3 \mathrm{~S}$ & $6 \mathrm{~S}$ \\
\hline module rated capacity, $\mathrm{Ah}$ & 221 & 6.5 \\
\hline module weight, $\mathrm{kg}$ & 30 & 1.05 \\
\hline number of modules used in the pack & 8 & 35 \\
\hline type of connection of modules in the pack & $8 \mathrm{~S}$ & $7 \mathrm{~S} 5 \mathrm{P}$ \\
\hline pack rated voltage, $\mathrm{V}$ & 48 & 50.4 \\
\hline pack rated capacity, $\mathrm{Ah}$ & 221 & 32.5 \\
\hline stored energy, $\mathrm{kWh}$ & 10.61 & 4.638 \\
\hline pack weight, $\mathrm{kg}$ & 240 & 40 \\
\hline specific energy for a pack, $\mathrm{Wh} / \mathrm{kg}$ & 44.2 & 920 \\
\hline specific power for a pack, $\mathrm{W} / \mathrm{kg}$ & $\sim 180$ & 650 \\
\hline allowable peak load, $\mathrm{A}$ & $\sim 1100$ & 20.7 at $99 \%$ SOC \\
\hline internal resistance of a pack, $\mathrm{m} \Omega$ & 21.0 at $99 \%$ SOC \\
& 23.2 at $75 \%$ SOC & 17.7 at $75 \%$ SOC \\
& 24.5 at 51\% SOC & 17.5 at 53\% SOC \\
\hline
\end{tabular}

As mentioned earlier, 35 of the $38 \mathrm{NiMH}$ modules were used in the newly-developed package. The remaining three unused modules remained in the package housing; to some extent, this reduces the specific energy and specific power of the pack. Leaving unused modules was necessary because, due to the expanding dimensions of modules during operation, they must work with appropriately small dilatations provided by the housing elements designed for 38 modules. Removal of three unnecessary modules would require designing a new housing or at least the laborious retrofitting of the existing housing, which was not needed at this stage. The initial value of the internal resistance of the NIMH battery pack obtained a very 
similar value to the resistance of the lead-acid battery pack, even though the NiMH battery has a significantly lower capacity and a larger number of cells connected in series. This indicates the special construction of the used NiMH cells for automotive applications. As known, the energy losses dissipated on heat depend on the internal resistance values. At a high resistance value, there would also be the need for significantly more intensive cooling of the pack.

From the point of view of using low-capacity batteries in an electric vehicle, the allowable value of the peak load is a very important parameter. For a newly developed package it is around $650 \mathrm{~A}$, which, with sufficient reserve, exceeds the value of the maximum current drawn by the motor of the tested vehicle, even at dynamic acceleration. This enables the use of the same settings of the vehicle motor controller with the original $48 \mathrm{~V}, 221$ Ah lead-acid battery pack.

\subsection{Measuring path}

In order to conduct measurements of the energy consumption of the tested vehicle, it was necessary to record the current drawn and returned to the battery and the battery voltage. The voltage measurement was made using a resistive voltage divider with an attenuation of 1:6 (to match the input range of the acquisition card), while the current was measured using a contactless sensor using the Hall effect with a sensitivity of $0.625 \mathrm{~V}$ per $150 \mathrm{~A}$. In addition, the temperature of the battery was also recorded using a thermistor sensor. The rotational speed of the motor was determined based on the Hall sensor signal giving five pulses per shaft revolution. The vehicle speed and the distance travelled were determined using a GPS device operating at a frequency of $10 \mathrm{~Hz}$. All signals were recorded in the measuring system on the memory card. The diagram of the measuring path and the main power circuit used in the test vehicle is shown in Fig. 4.

The battery temperature sensor was placed in one of the modules close to the centre of the pack in the space provided for this purpose.

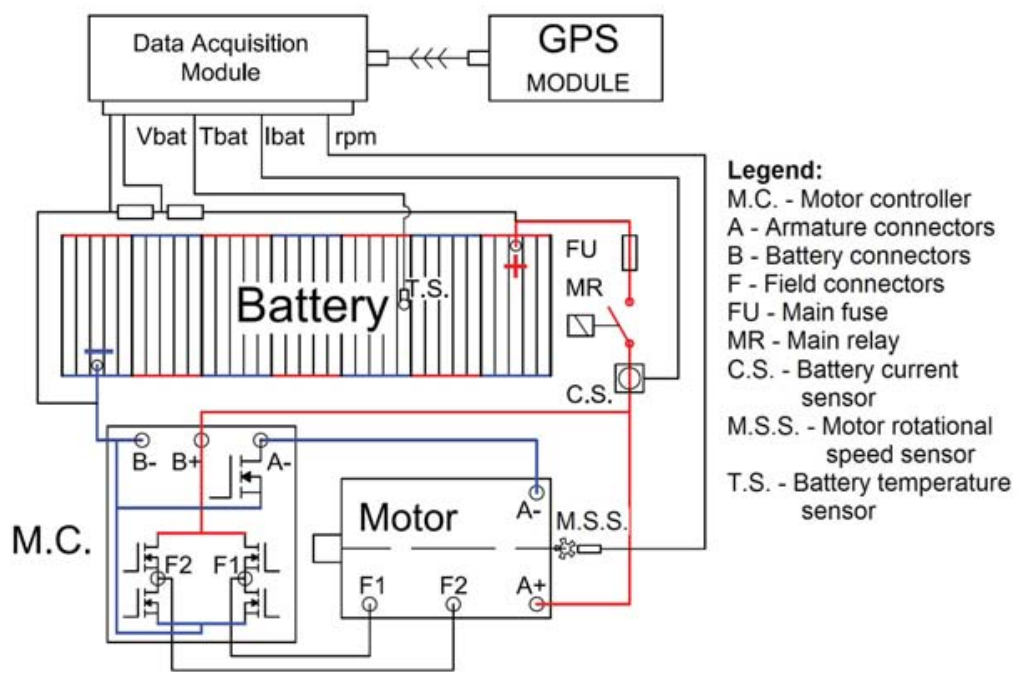

Fig. 4. Diagram of the measuring path with the main power circuit applied in the test vehicle 


\section{Results}

\subsection{Experimental tests}

Two test drives were performed on a vehicle equipped with a NiMH battery pack. Both test routes were started with a battery charged to $100 \%$ SOC. In the first case, the lead-acid battery remained in the vehicle, which resulted in a total vehicle weight of $740 \mathrm{~kg}$ including the driver. In the second case, lead-acid batteries with a total weight of $240 \mathrm{~kg}$ were removed from the vehicle, so the gross weight of the vehicle was $500 \mathrm{~kg}$. To have both speed profiles as similar as possible, the vehicle was driven by the same driver in both cases. Test drives were conducted at the Czyżyny campus of Cracow University of Technology in Krakow on roads with a flat and smooth surface, mainly asphalt, and with a shorter concrete section. In the area where the tests were performed, regular traffic has access (low to moderate intensity and at a speed limit of $30 \mathrm{~km} / \mathrm{h}$ ). In situations in which regular traffic was present, it was not possible to obtain two identical vehicle speed profiles for both tests. However, it was decided that the vehicle would be driven by one driver, maintaining the same driving style for both tests and the same average speed of movement across the entire ride. The same conditions produced very good results in earlier studies of the same vehicle equipped with lead-acid batteries (these results are the subject of a separate article). A linear dependence of the energy drawn from the battery on the distance travelled by the vehicle was reached.

The main goal of the research was to determine the energy consumption of a vehicle equipped with a set of $\mathrm{NiMH}$ batteries and the influence of its total weight on energy consumption. The amount of energy taken from the battery while driving $E_{d r v+}$ was determined by the equation (1):

where:

$$
E_{d r v+}=\int_{t_{0}}^{t_{1}} V \cdot I d t, \text { for } I>0
$$

$V$ - battery voltage, $\mathrm{V}$

I - battery current, A

$t$ - time, s

$t_{0}$ - time of the start of driving, $s$

$t_{1}$ - time of the end of driving, $s$

The amount of energy delivered to the battery $E_{d r v-}$ during regenerative braking was determined by the equation (2):

$$
E_{d r v-}=\int_{t_{0}}^{t_{1}} V \cdot I d t, \text { for } I<0
$$

Finally, the balance of energy used during driving, including the energy returned to the battery during regenerative braking, was calculated using formula (3):

$$
E_{d r v}=E_{d r v+}+0.8 \cdot E_{d r v-}
$$


The value of 0.8 refers to the coulombic efficiency of the used battery. This means that on average, $80 \%$ of the charge returned to the battery raises its charge, the rest is dissipated to heat. The obtained value was determined using a diagnostic tester based on the registration of the battery charging current and the SOC increment in a hybrid-drive management system. The examined vehicle uses NiMH batteries with parameters very similar to those used in this work. Coulombic efficiency values adopted in the hybrid vehicle manufacturer's calculation model are also confirmed in other written materials, e.g. [24].

Figure 5 shows plots of the current and voltage of the battery while driving a vehicle with a gross weight of $740 \mathrm{~kg}$.

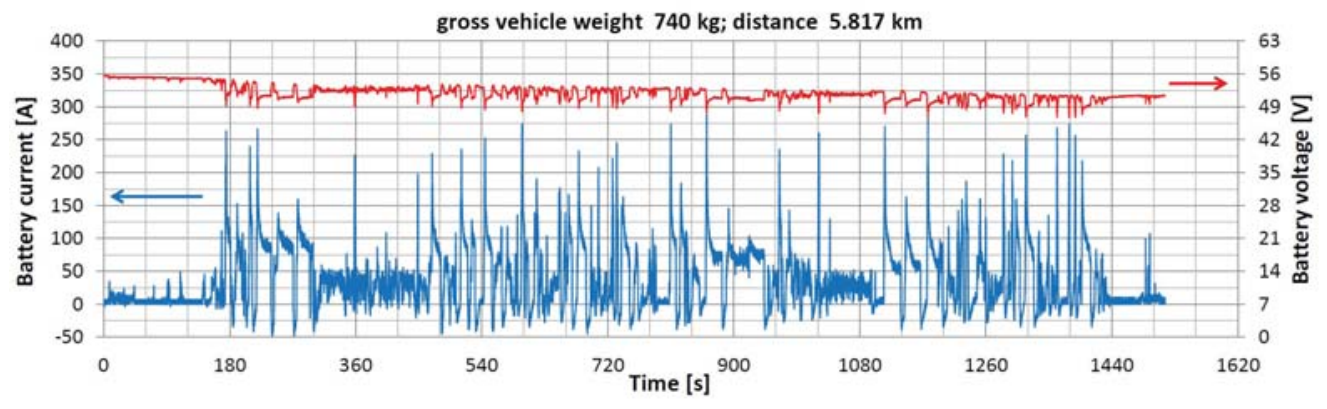

Fig. 5. Battery current and battery voltage as a function of time during the test drive of vehicle with a weight of $740 \mathrm{~kg}$

The open-circuit battery voltage $V_{o c}$ at the beginning of the measurement was $55.6 \mathrm{~V}$. After finishing the drive, the $V_{o c}$ voltage was $51.4 \mathrm{~V}$. The lowest recorded voltage during the acceleration of the vehicle with a partially discharged battery was $46.71 \mathrm{~V}$. The battery current during the acceleration of the vehicle often exceeded $250 \mathrm{~A}$, reaching a maximum value of 287.1 A. The highest value of the current during regenerative braking was $48.4 \mathrm{~A}$.

Figure 6 shows the plot of vehicle speed and battery temperature over time while driving a vehicle with a total weight of $740 \mathrm{~kg}$.

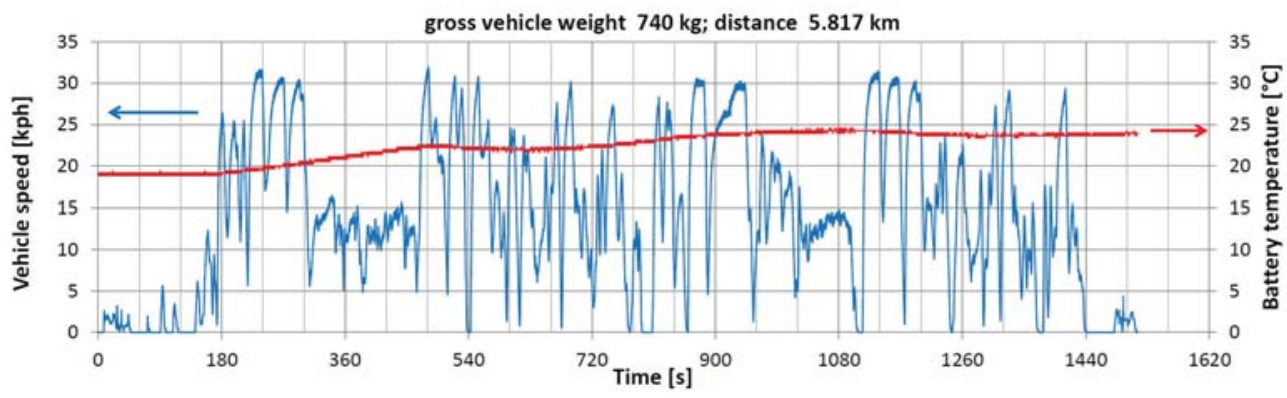

Fig. 6. Vehicle speed and battery temperature as a function of time during the test drive of vehicle with a weight of $740 \mathrm{~kg}$ 
The maximum vehicle speed was $31.9 \mathrm{~km} / \mathrm{h}$ and the temperature of the battery increased from an initial value of $19^{\circ} \mathrm{C}$ to a maximum value of $24.5^{\circ} \mathrm{C}$ obtained around 1,080 seconds after the start of the test drive.

Figure 7 shows the current and voltage course of the battery when driving a vehicle with a weight of $500 \mathrm{~kg}$.

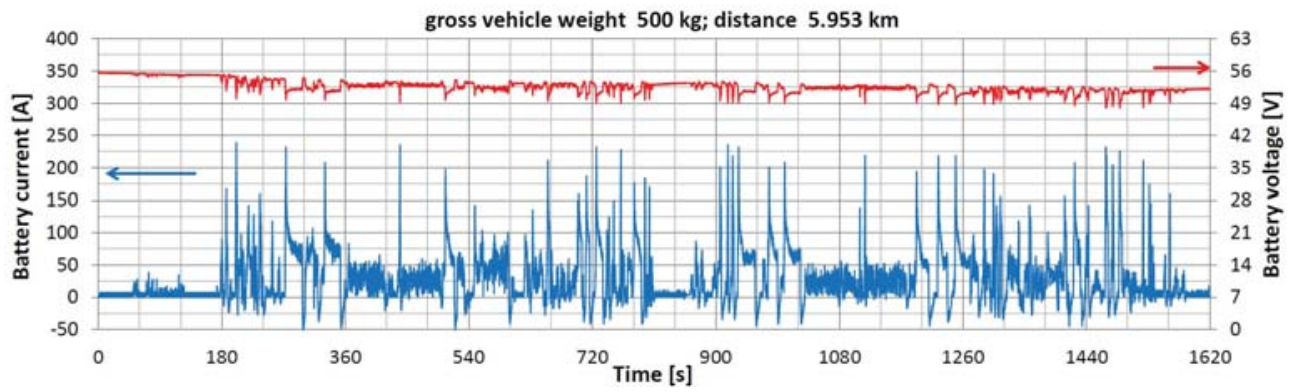

Fig. 7. Battery current and battery voltage as a function of time during the test drive of vehicle with a weight of $500 \mathrm{~kg}$

The open-circuit battery voltage $V_{o c}$ at the beginning of the measurement was $55.59 \mathrm{~V}$. Following completion of the route, the $V_{o c}$ voltage was $52.05 \mathrm{~V}$. The lowest recorded voltage during the acceleration of the vehicle was $47.91 \mathrm{~V}$. Battery current during the acceleration of the vehicle did not exceed $250 \mathrm{~A}$ reaching the maximum value of $238.6 \mathrm{~A}$. The highest value of current during regenerative braking was $51.9 \mathrm{~A}$.

Figure 8 shows a plot of vehicle speed and battery temperature over time while driving a vehicle with a weight of $500 \mathrm{~kg}$.

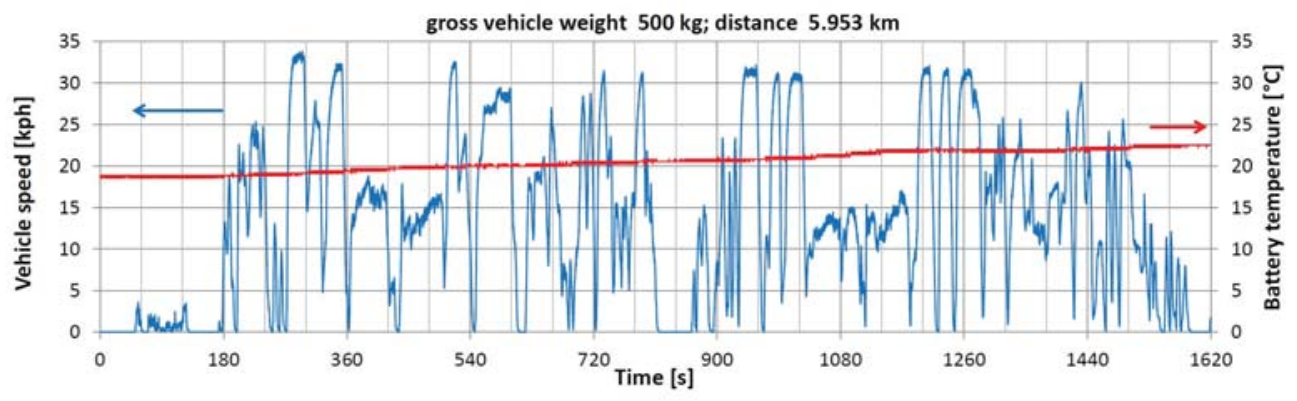

Fig. 8. Vehicle speed and battery temperature as a function of time during the test drive of vehicle with a weight of $500 \mathrm{~kg}$

The maximum vehicle speed reached $33.84 \mathrm{~km} / \mathrm{h}$ and the temperature of the battery increased from an initial value of $18.9^{\circ} \mathrm{C}$ to a maximum value of $22.8^{\circ} \mathrm{C}$ at the end of the test drive.

A summary of the most important results obtained for both test drives is shown in Table 5. 
Table 5. Results of both of the test drives

\begin{tabular}{|c|c|c|}
\hline Experimental test results & $\begin{array}{c}\text { Vehicle } \\
\text { weight 740 kg }\end{array}$ & $\begin{array}{c}\text { Vehicle } \\
\text { weight 500 kg }\end{array}$ \\
\hline test duration, s & 1512.1 & 1600.7 \\
\hline distance travelled, km & 5.817 & 5.953 \\
\hline maximum current drawn from the battery, A & 287.1 & 238.6 \\
\hline maximum regenerative braking current. A & 51.9 & 48.4 \\
\hline minimum battery voltage under load, $\mathrm{V}$ & 46.71 & 47.91 \\
\hline energy drawn from the battery Edrv+, kWh & 0.856 & 0.707 \\
\hline energy of regen. braking measured on the battery Edrv-, $\mathrm{kWh}$ & -0.061 & -0.051 \\
\hline energy of regen. braking stored in the battery, $\mathrm{kWh}$ & -0.049 & -0.041 \\
\hline energy balance Edrv, $\mathrm{kWh}$ & 0.807 & 0.666 \\
\hline specific energy consumption, $\mathrm{kWh} / \mathrm{km}$ & 0.139 & 0.112 \\
\hline specific energy consumption per $1 \mathrm{t}$ of vehicle weight, $\mathrm{kWh} /(\mathrm{km} \cdot \mathrm{t})$ & 0.187 & 0.224 \\
\hline maximum vehicle speed, $\mathrm{km} / \mathrm{h}$ & 31.9 & 33.84 \\
\hline
\end{tabular}

As can be seen in Table 5, the specific energy consumption for a vehicle with a $32 \%$ lower weight is lower by only $20 \%$; thus, specific energy consumption related to one ton of vehicle weight is significantly higher in the case of the lower-weight vehicle.

\subsection{ADVISOR software and vehicle model}

The simulation model of the tested vehicle was executed in the Advisor program [11]. The Advisor environment, in this case release r0116, uses the power of the Matlab/Simulink scientific calculation package [26]. The Advisor environment allows, among other features, the evaluation of an energy management strategy for an electric vehicle's propulsion system. The subsystem models used in the program are based on test data and are quasi-static, assuming constant values in a given calculation step. The user must provide measured or estimated data that define the vehicle and its components. The program's construction is modular, which enables the easy modification of components. Figure 9 shows the course of simulation calculations with separated blocks which correspond to individual vehicle components. Additionally, the main test vehicle parameters used in the developed model are presented in red boxes. Blue arrows indicate the modules in which appropriate parameters are defined.

As can be seen in Fig. 9, in each block, the required values of vehicle speed and torque are converted, taking into account the available values. In the first block (drive cycle), the required vehicle speeds are defined for each second of the cycle. In each subsequent block, up to the electric motor that produces the drive torque, losses of energy at this stage conversion are taken into account. Finally, the values of the torque required in a given step are calculated. This information is then passed to the preceding blocks in which the real values are determined, taking into account input data and losses on the energy conversion path. Finally, the 'veh' 


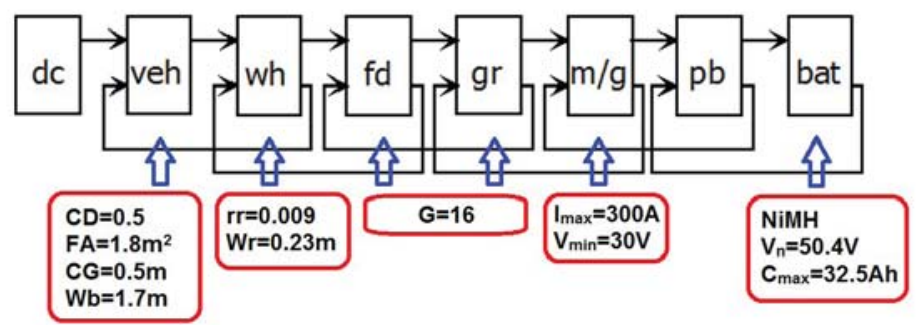

Fig. 9. Data flow in the Advisor model of the electric vehicle with test vehicle parameters used in the developed model

Abbreviations in Fig. 9:

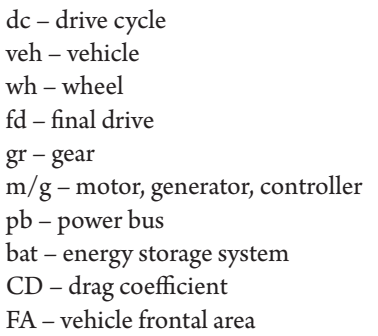

$\mathrm{CG}$ - centre of gravity height

$\mathrm{Wb}$ - wheelbase

$\mathrm{rr}$ - rolling resistance coefficient

$\mathrm{Wr}$-wheel radius

$\mathrm{G}$ - gear ratio (total for gr and $\mathrm{fd}$ )

Imax - motor maximum current

Vmin - motor minimum voltage

Cmax - battery capacity

$\mathrm{Vn}$ - battery nominal voltage

block calculates the vehicle speed after taking into account the traction force; the result is used to determine the acceleration value in the next step.

The simulation uses a simple thermal model of a NiMH battery in connection with parallel air cooling. The operating parameters of the battery are characterised by the serial connection of the internal resistance of the battery and voltage at the terminals of the battery being treated as an ideal voltage source. The battery power is limited by the maximum value that can be supplied by the system on the one hand and by the maximum power that the motor can take on the other. The model uses a parallel cooling air flow along each battery module. This approach ensures a fairly even temperature distribution between the modules and the individual cells. The simulation model of the NiMH battery used for the tested vehicle is based on the data obtained in the laboratory tests of NREL [26]. The internal resistance of the cells is shown in the form of a look-up table indexed by the level of the battery cells SOC. Separate tables are valid for the charging mode and for the discharging mode. Based on this data, an open circuit voltage $V_{O C}$ is obtained for a module composed of six cells connected in series. The $V_{O C}$ values are also presented in the model in the form of an array indexed with the SOC level. The value of the available power is the result of the model's operation. The electrical parameters calculated in the model are given as follows:

Battery power $P$ is calculated using formula (4):

$$
P=\left(V_{O C} \cdot I\right)-R I^{2}
$$

where:

$V_{\text {OC }}$ - open-circuit voltage of battery, $\mathrm{V}$

$R \quad$ - battery internal resistance, $\Omega$

I - battery current, A 
After transformation, the following formula (5) is obtained:

$$
R I^{2}-\left(V_{\text {OC }} \cdot I\right)+P=0
$$

From the two possible solutions, one rejects the solution in which the same power is obtained through extremely high currents and low voltages.

The SOC calculation provides the present amount of charge in the battery and is calculated using formula (6) based on values of battery capacity $C_{M A X}$ and battery charge used up to the moment of SOC calculation $C_{U S}$ :

$$
S O C=\frac{C_{M A X}-C_{U S}}{C_{M A X}}
$$

The electric motor model is based on an efficiency look-up table, which is indexed by the rotational speed of the rotor and the motor torque. The available motor torque is calculated on the basis of the available power. The model takes into account the power losses in the form of heat excreted externally through convection, radiation and heat exchange in the cooling system. The vehicle model used in the simulation is based on classic vehicle dynamics equations and takes into account the rolling resistance, aerodynamic drag and the strength necessary to climb a gradient. First, the traction force for a given acceleration is calculated, and then the acceleration achieved at a given traction force. During the calculation step (1s), the vehicle speed is the mean value of the speed at the end of the previous calculation step and the speed required at the end of the current step.

Creation of the calculation model consists of setting the required parameters, e.g. motor parameters, vehicle weight, gear ratio and, motor efficiency map. A model of the applied Prius modules was implemented in Advisor; this simplified creating the vehicle model. The remaining required parameters were adopted from the technical data set of the tested vehicle - the most important of these are presented in Fig. 9.

\subsection{Simulation results}

Both of the actual test drives were characterised by a similar style of driving and distance covered. The speed profiles of both test runs were registered and used to prepare driving tests for simulations. For driving cycles in the simulations, digitised speed profiles of real vehicles registered during road tests were used. In the same way as in the case of experiments, two simulation tests were carried out:

1. Test drive of a vehicle with a total weight of $740 \mathrm{~kg}$

2. Test drive of a vehicle with a total weight of $500 \mathrm{~kg}$

The simulation results for the case of the vehicle with a total weight of $740 \mathrm{~kg}$ are shown in Fig. 10.

Similarly, Fig. 11 shows the results for the vehicle with a total weight of $500 \mathrm{~kg}$. 

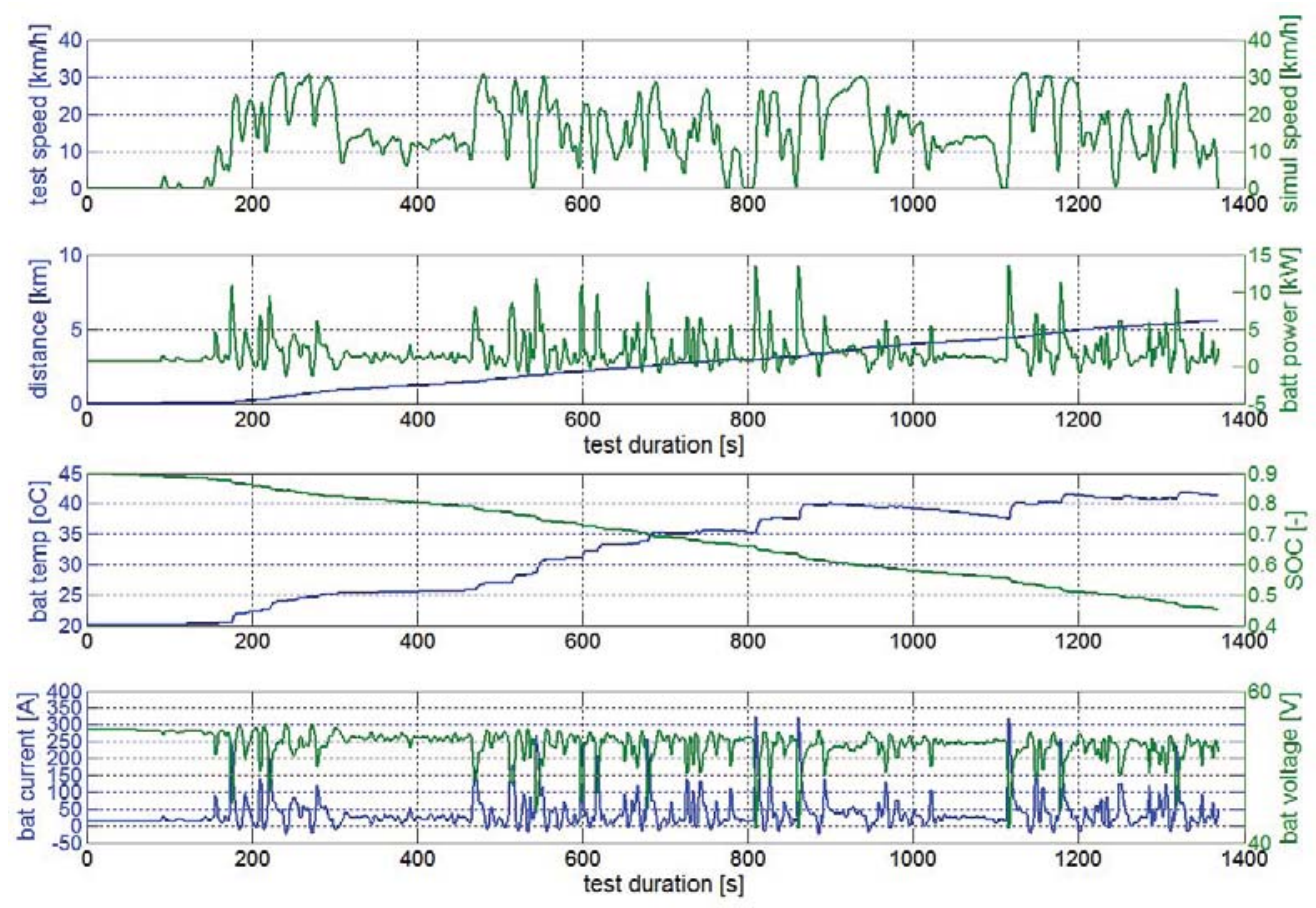

Fig. 10. Results of the simulation of EV with a total weight of $740 \mathrm{~kg}$
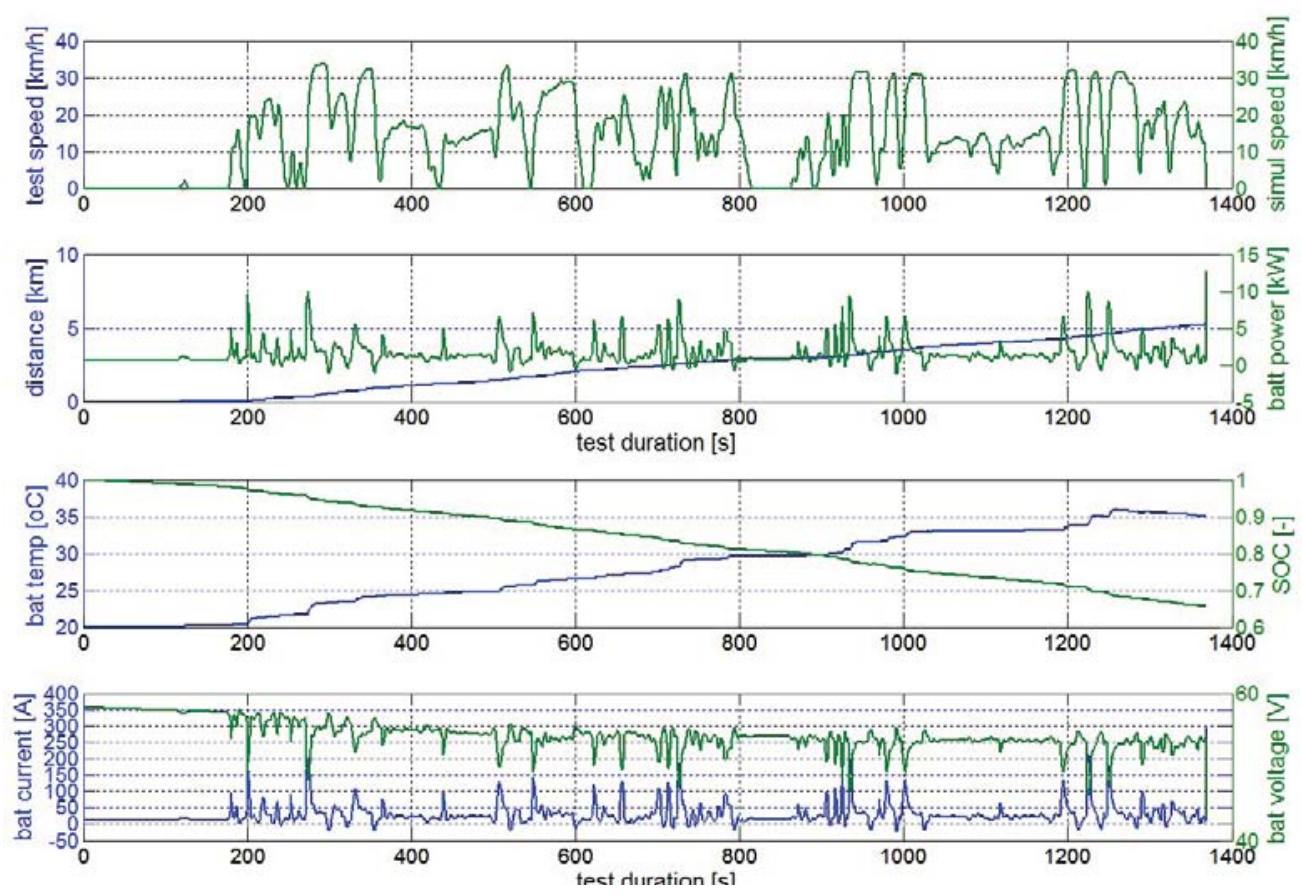

Fig. 11. Results of the simulation of EV with a total weight of $500 \mathrm{~kg}$ 
Due to the slightly different speed profiles, a shorter distance for the vehicle weighing 500 $\mathrm{kg}$ was achieved. The lighter vehicle used a little less energy - the specific energy consumption was $0.14 \mathrm{kWh} / \mathrm{km}$ for the vehicle with a weight of $740 \mathrm{~kg}$ and $0.12 \mathrm{kWh} / \mathrm{km}$ for the vehicle with a weight of $500 \mathrm{~kg}$. The maximum values of the current drawn from the batteries reached 322.7 A and 294.85 A and occurred during fast acceleration values of the vehicle. Table 6 shows the main results of the driving test simulation in both cases - the vehicle with a total weight of $740 \mathrm{~kg}$ and the vehicle with a total of weight $500 \mathrm{~kg}$.

Table 6. Driving test simulation results for both cases of total vehicle weight

\begin{tabular}{|c|c|c|}
\hline Simulation test results & $\begin{array}{c}\text { Vehicle weight } \\
\mathbf{7 4 0} \mathbf{~ k g}\end{array}$ & $\begin{array}{c}\text { Vehicle weight } \\
\mathbf{5 0 0} \mathbf{~ k g}\end{array}$ \\
\hline drive test duration, $\mathrm{s}$ & 1370 & 1370 \\
\hline distance travelled, km & 5.57 & 5.23 \\
\hline used battery charge, \% SOC & 45 & 35 \\
\hline maximum current drawn from the battery, A & 322.7 & 294.85 \\
\hline maximum regenerative braking current, A & 25.13 & 22.5 \\
\hline maximum battery voltage under load (at start), $\mathrm{V}$ & 55.7 & 55.5 \\
\hline minimum battery voltage under load (end of test), V & 42.0 & 42.89 \\
\hline energy consumed during the test, $\mathrm{kWh}$ & 0.79 & 0.62 \\
\hline specific energy consumption, $\mathrm{kWh} / \mathrm{km}$ & 0.14 & 0.12 \\
\hline maximum motor torque, $\mathrm{Nm}$ & 26.73 & 22.91 \\
\hline maximum vehicle speed, $\mathrm{km} / \mathrm{h}$ & 31.15 & 33.7 \\
\hline
\end{tabular}

The results of the vehicle driving simulation using the same conditions as the actual test drives indicated strong conformity of the specific energy consumption between simulation and reality. Therefore, in the next step, further simulations were performed to estimate the range of the vehicle equipped with a newly developed lightweight energy storage system. It was assumed that the vehicle would travel starting from $100 \%$ SOC down to $10 \%$ SOC, which is a safe value for NiMH batteries. Unlike lead-acid batteries, as well as most lithiumbased batteries, this value does not significantly reduce the NiMH battery life cycle. Figure 12 presents the result of the simulation aimed at showing the maximum range of the vehicle with a total weight of $740 \mathrm{~kg}$ using $90 \%$ SOC. The test was conducted until $10 \%$ of the initial charge remained in the battery. To estimate the range, a multiplied, the same real speed profile was used.

After $2960 \mathrm{~s}$ and $90 \%$ of battery charge consumed, the tested vehicle travelled $10.92 \mathrm{~km}$. At the end of the simulation, as a result of the degradation of the electrical parameters of the battery, an increasing discrepancy between the required speed and the resultant simulation began to appear. The maximum discrepancy reached $6 \mathrm{~km} / \mathrm{h}$. Figure 13 presents the result of a similar simulation aimed at showing the maximum range of the vehicle with a total weight of $500 \mathrm{~kg}$ using $90 \%$ SOC. 


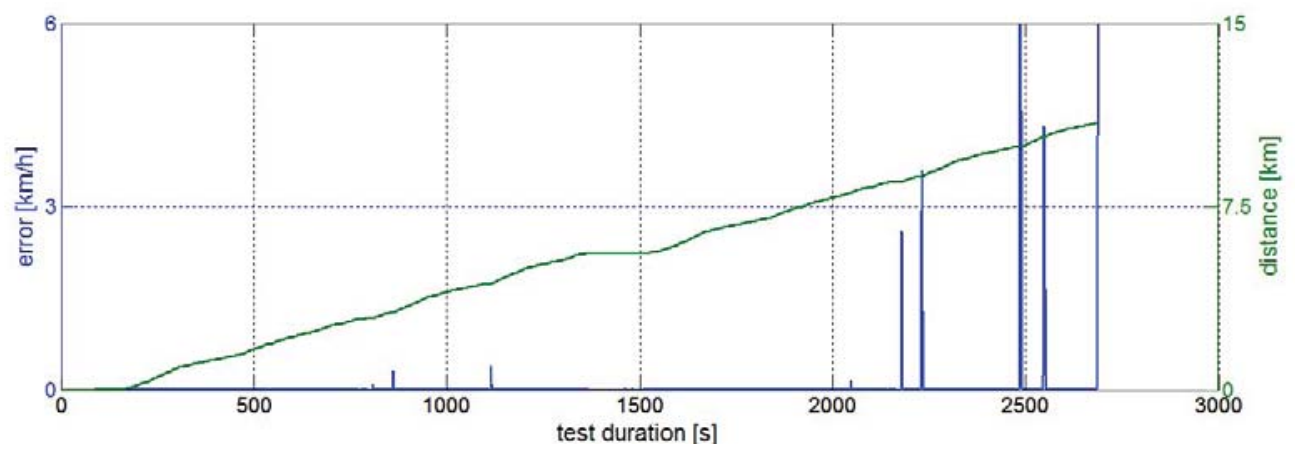

Fig. 12. EV range with a weight of $740 \mathrm{~kg}$ after using $90 \%$ of the charge

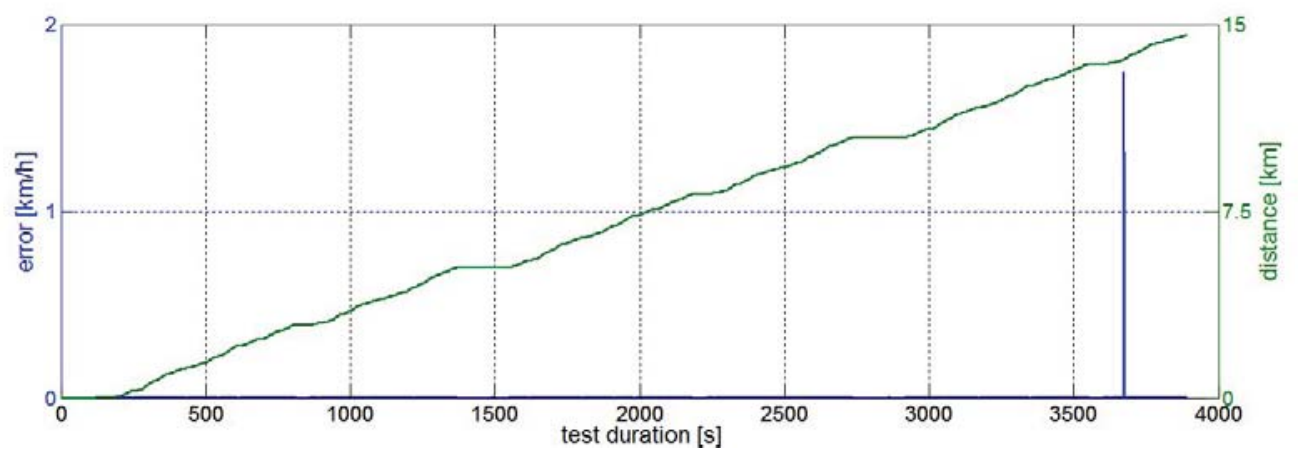

Fig. 13. EV range with a weight of $500 \mathrm{~kg}$ after using $90 \%$ of the charge

Similar to the previous case, as a result of the degradation of the electrical parameters of the battery, an increasing discrepancy between the required speed and the resultant simulation began to appear at the end of the simulation. The maximum discrepancy reached $1.7 \mathrm{~km} / \mathrm{h}$. Non-compliance of the real speed in relation to the required speed is not high and occurs incidentally. The results obtained in both cases (total vehicle weights of $740 \mathrm{~kg}$ and $500 \mathrm{~kg}$ ) are listed in Table 7.

Table 7. Vehicle range and energy parameters after using $90 \%$ of battery energy

\begin{tabular}{|c|c|c|}
\hline Test results after using 90\% of battery energy & Vehicle weight $\mathbf{7 4 0 ~} \mathbf{k g}$ & Vehicle weight $\mathbf{5 0 0 ~} \mathbf{~ g g}$ \\
\hline vehicle range, $\mathrm{km}$ & 10.92 & 12.98 \\
\hline test duration, $\mathrm{s}$ & 2,960 & 3,469 \\
\hline energy consumed, $\mathrm{kWh}$ & 1.56 & 1.56 \\
\hline specific energy consumption, $\mathrm{kWh} / \mathrm{km}$ & 0.14 & 0.12 \\
\hline regenerative braking energy, $\mathrm{kWh}$ & 0.03 & 0.022 \\
\hline
\end{tabular}

The estimated vehicle range was slightly below $11 \mathrm{~km}$ for the vehicle with the higher weight, and almost $13 \mathrm{~km}$ for the vehicle without load; this is as predicted. However, it should be remembered that this relates to a new pack of batteries. In the case of used batteries, it will undeniably be lower, depending on the degree of battery wear. 


\section{Discussion}

Analysing the results of experimental studies, it can be concluded that:

- When driving with a higher load, the battery current has higher peak values during acceleration; this is due to the increased motor load and the higher inertia forces of the heavier vehicle.

- During braking, slightly higher peak battery currents were obtained for the vehicle with the lower weight; this results from the slightly higher maximum speed of the vehicle without an additional load.

- The specific energy consumption of the vehicle with the higher weight is slightly higher than that of the vehicle without an additional load; this is caused by the high participation of the motion resistance of the vehicle independent of load, such as parasitic frictional losses in the drivetrain or and air resistance force.

- The temperature of the battery in the vehicle with a higher weight obtained a higher value at the end of the test drive; this is due to the higher average battery current when driving with an additional load.

The results of the simulations performed on the vehicle model in the Advisor program indicated that a good convergence of the results of specific energy consumption depending on the vehicle weight was obtained. This was the overriding goal of the simulation research and this goal should be considered as having been achieved. The results for the less important parameters, i.e. peak currents and battery voltage, show some discrepancies in relation to the results of measurements on the real vehicle. This is due to the inevitable simplifications adopted in the model resulting from a lack of complete data regarding, for example, the motor efficiency map. An improvement in this matter would require a series of tedious motor tests. Discrepancies between the battery temperature results obtained in the experiment and the results of simulations from the difference in the place where the battery temperature is determined in the simulation and where it is measured in the vehicle. The temperature obtained by simulation refers to the inside of the battery; however, it is in fact only possible to measure the temperature in the hollow of the module housing made of plastic. Simulations carried out in the Advisor program also provide results that may be problematic to obtain in real-world measurements. This applies, for example, to the curve of motor torque during the test. The maximum values of this parameter are included in Table 6. It should also be noted that the simulation with the used tool also has some limitations. It is not possible to take into account the variable slope of the road or external factors such as wind. In the presented situation, this is not a serious problem, because the place of application of the vehicle under consideration (e.g. in a factory) significantly limits the possibility of vehicle exposure to such variable factors.

Using the acquired experience, further work in this topic will be executed in the direction of developing a system that determines the actual state of charge of the battery and the estimated range of the vehicle. It is important to note that the test vehicle is also used in the work of the student scientific association, in which a prototype of a range-extender with a low-emission internal combustion engine powered with hydrogen is being developed. 


\section{Summary and conclusions}

The newly-developed lightweight energy storage system based on NiMH batteries has fulfilled its task in the light-duty electric vehicle. The drive system of the vehicle functions properly. The assumed goal of the work has been achieved. It was possible to significantly increase the loading capacity of the vehicle at the expense of reducing the range. The other main traction parameters of the vehicle were retained. From the user perspective, the vehicle operates no worse than it did when equipped with the original lead-acid battery. Due to slightly higher rated voltage of the newly-developed battery pack and the lower weight of the unloaded vehicle, the maximum speed increases by $2 \mathrm{~km} / \mathrm{h}$ compared with a vehicle equipped with the factory lead-acid batteries. Determining the behaviour of a new battery in the long term would require more extensive exploitation tests.

Simulation tests confirmed that the vehicle and battery model developed in the Advisor program meets the main expectations, i.e. it allows estimating the vehicle's range depending on the load or style of the vehicle with satisfactory accuracy. It should be remembered that the driving methods (speed profile) was not exactly the same during both test drives; however, the authors made every effort to reach the greatest possible similarity of profiles using the available resources. A sufficient development of the mathematical model of the vehicle created in the Matlab/Advisor environment allows conducting other more extensive predictive research in the future, especially regarding the range of the vehicle depending on its load. This can be achieved in a short time, without conducting additional experimental tests.

The vehicle range estimated by way of simulation with battery levels from full charge to $10 \%$ SOC was approximately $13 \mathrm{~km}$ for a vehicle with a new battery and no load. For a vehicle with a $240 \mathrm{~kg}$ load, a range of around $11 \mathrm{~km}$ was obtained, which confirmed the initial predictions about the range of the vehicle with a NiMH battery of lower capacity about $10 \mathrm{~km}$. Real-world full-load vehicle tests will be possible after the integration of a new battery in the space provided for the mounting of the original lead-acid battery and the installation of a cargo box.

During the experimental tests, the minimum intensity of regenerative braking was defined in order to minimise the impact of this process on the obtained results of energy consumption by the vehicle. NiMH batteries can tolerate high-current charging well (unlike lead-acid batteries), hence the possibility to adjust the generating braking parameters to a higher intensity. This would certainly increase the braking energy recovery rate, reducing the energy consumption of vehicle motion. The next works in this topic will be conducted in this area.

In summary, in special applications of light-duty electric vehicles, the nickel-metal-hydride battery originally foreseen for a hybrid vehicle can be an interesting alternative to not only the commonly used lead-acid batteries, but also to the recently increasingly appearing lithium-ion batteries. However, recent developments in large-capacity NiMH batteries described in the first part of this work give hope that this technology may also appear once again in full-size electric vehicles. 
This research was conducted in the framework of task No. M-4/443/2017/DS, which was a subsidy for research granted by the Ministry of Science and Higher Education of the Republic of Poland.

The authors of the article would like to thank the Head of the Institute of Automobiles and Internal Combustion Engines of Cracow University of Technology, Prof. Marek Brzeżanski for acquiring the Prius battery pack from the Toyota Motor Poland Company for research purposes, who was represented in this process by Dr. Andrzej Szatek, to whom the authors are also grateful.

\section{References}

[1] Aditya J.P., Ferdowsi M., Comparison of NiMH and Li-ion batteries in automotive applications, Proceedings of 2008 IEEE Vehicle Power and Propulsion Conference, Harbin, China, 3-5 September 2008, 10.1109/vppc.2008.4677500.

[2] Bazaras Z., Timofeev B., Vasilieva N., Vilkauskas A., Raslavicius L., Keršys R., Current state of the global electric power engineering, Proceedings of $16^{\text {th }}$ International Scientific Conference Transport Means 2012, Kaunas, Lithuania, 25-26 $6^{\text {th }}$ October 2012, 267-269.

[3] Brooke L, Not dead yet: The resilient ICE looks to 2050, Automotive Engineering, vol. 5(4), 2018, 22-23.

[4] Feng X., Ouyang M., Liu X., Lu L., Xia Y., He X., Thermal runaway mechanism of lithium ion battery for electric vehicles: A review, Energy Storage Materials, vol. 10, 2018, 246267, 10.1016/j.ensm.2017.05.013.

[5] Gaines L., The future of automotive lithium-ion battery recycling: Charting a sustainable course, Sustainable Materials and Technologies, 1-2, 2014, 2-7, 10.1016/j. susmat.2014.10.001.

[6] Hao H., Mu Z., Jiang S., Liu Z., Zhao F., GHG Emissions from the Production of LithiumIon Batteries for Electric Vehicles in China, Sustainability, vol. 9(4), 2017, 504, 10.3390/ su9040504.

[7] Johnson N.M., Battery technology for $\mathrm{CO}_{2}$ reduction, [in:] Folkson, R., (Ed.): Alternative Fuels and Advanced Vehicle Technologies for Improved Environmental Performance, Woodhead Publishing, Sawston, 2014, 582-631, 978-0-85709-522-0.

[8] Juda Z., Noga M., The influence of battery degradation level on the selected traction parameters of a light-duty electric vehicle, IOP Conf. Ser.: Mater. Sci. Eng., vol. 148, 2016, 012042, 10.1088/1757-899x/148/1/012042.

[9] Karden E., Development trends for future automobiles and their demand on the battery, [in:] Garche J., Karden E., Moseley P. T., Rand D.A.J., (Eds.): Lead-Acid Batteries for Future Automobiles, Elsevier, Amsterdam, 2017, 3-25, 978-0-44463-700-0.

[10] Luo W., Zhu S., Gong J., Zhou Z., Research and Development of Fire Extinguishing Technology for Power Lithium Batteries, Procedia Engineering, vol. 211, 2018, 531-537, 10.1016/j.proeng.2017.12.045. 
[11] Markel T., Brooker A., Hendricks T., Johnson V., Kelly K., Kramer B., O’Keefe M., Sprik S., Wipke K., ADVISOR: A systems analysis tool for advanced vehicle modeling, J of Power Sources, vol. 110(2), 2002, 255-266, 10.1016/s0378-7753(02)00189-1.

[12] Noga M., Various aspects of research of the SI engine with an additional expansion process, MATEC Web of Conferences, vol. 118, 2017, 00017, 10.1051/ matecconf/201711800017.

[13] Noga M., Juda Z., Energy Efficiency of a Light-Duty Electric Vehicle, Proceedings of 21st International Scientific Conference Transport Means 2017, Juodkrante, Lithuania, 20-22 September 2017, 78-85.

[14] Onomura Y., Inazu M., Ito M., Minohara T., Nozaki K., Secondary Battery Development for Hybrid Vehicles at Toyota, Toyota Technical Review, vol. 57(2), 2011, 9-18.

[15] Saga K., Development of Powertrain Technology for Even Better Fuel Efficiency. Toyota Technical Review, vol. 60, 2014, 4-12.

[16] Shin J.W., Kim J.O., Choi J.Y., Oh S.H., Design of 2-speed transmission for electric commercial vehicle, International Journal of Automotive Technology, vol. 15(1), 2014, 145-150, 10.1007/s12239-014-0016-8.

[17] Ślaski G., Ohde B., A statistical analysis of energy and power demand for the tractive purposes of an electric vehicle in urban traffic - an analysis of a short and long observation period, IOP Conf. Ser.: Mater. Sci. Eng., vol. 148, 2016, 012027, 10.1088/1757899X/148/1/012027.

[18] Xing Y., Ma E.W., Tsui K.L., Pecht M., Battery Management Systems in Electric and Hybrid Vehicles, Energies, vol. 4(11), 2011, 1840-1857, doi:10.3390/en4111840.

[19] Yan S., Meng T., Young K., Nei J., A Ni/MH Pouch Cell with High-Capacity $\mathrm{Ni}(\mathrm{OH})_{2}$, Batteries, vol. 3(4), 2017, 38, 10.3390/batteries3040038.

[20] Yan S., Nei J., Li P., Young K., Ng, K., Effects of $\mathrm{Cs}_{2} \mathrm{CO}_{3}$ Additive in $\mathrm{KOH}$ Electrolyte Used in Ni/MH Batteries, Batteries, vol. 3(4), 2017, 41, 10.3390/batteries3040041.

[21] Young K.H., Research in Nickel/Metal Hydride Batteries 2016, Batteries, vol. 2(4), 2016, 31, 10.3390/batteries2040031.

[22] Young K.H., Ng K.Y.S., Bendersky L.A., A Technical Report of the Robust Affordable Next Generation Energy Storage System-BASF Program, Batteries, vol. 2(1), 2016, 2, 10.3390/ batteries2010002.

[23] Zhu J.H., Liu C.T., Pike L.M., Liaw P.K., A thermodynamic interpretation of the size-ratio limits for laves phase formation, Metallurgical and Materials Transactions A, vol. 30(5), 1999, 1449-1452, 10.1007/s11661-999-0292-5.

[24] Zhu W.H., Zhu Y., Davis Z., Tatarchuk B.J., Energy efficiency and capacity retention of NiMH batteries for storage applications, Applied Energy, vol. 106, 2013, 307-313, 10.1016/j. apenergy.2012.12.025.

[25] 20TruthsAbouttheGMEV1ElectricCar,http://web.archive.org/web/20090123001021/ http://www.greencar.com:80/features/gm-evl/ (access: 30.06.2018).

[26] ADVISOR Documentation, http://adv-vehicle-sim.sourceforge.net/advisor_doc.html (date of access 2018-06-30). 
[27] BU-107: Comparison Table of Secondary Batteries, https://batteryuniversity.com/learn/ article/secondary_batteries (access: 15.05.2018).

[28] Patent encumbrance of large automotive NiMH batteries, https://en.wikipedia.org/wiki/ Patent_encumbrance_of_large_automotive_NiMH_batteries (access 30.06.2018). 